\title{
Thirty years of Landscape Ecology (1987-2017): retrospects and prospects
}

\author{
Jianguo Wu
}

Received: 13 November 2017/ Accepted: 16 November 2017/Published online: 24 November 2017

(C) Springer Science+Business Media B.V., part of Springer Nature 2017

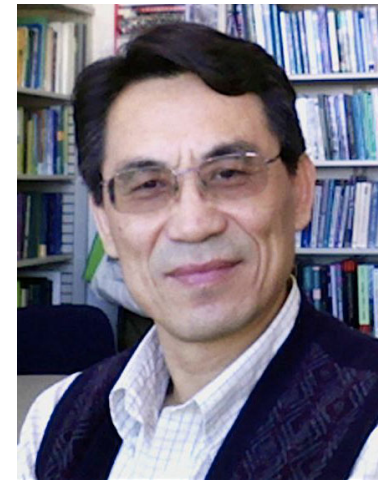

This is a tribute to the 30th anniversary of the journal, Landscape Ecology, the flagship journal of the International Association for Landscape Ecology (IALE) which was founded in 1982. Landscape Ecology was launched in 1987, with Frank B. Golley at the helm as the founding Editor-in-Chief. The first Editorial Board consisted of 18 leading landscape ecologists, 10 from Europe, 6 from North American, and 2 from Asia

\section{J. Wu $(\bowtie)$}

School of Life Sciences, School of Sustainability, and Julie A. Wrigley Global Institute of Sustainability, Arizona State University, Tempe AZ 85287-4501, USA e-mail: Jingle.Wu@asu.edu

J. Wu

Center for Human-Environment System Sustainability (CHESS), Beijing Normal University, 100875 Beijing, China
(Fig. 1). During the past 30 years, the journal has grown rapidly from a tiny new journal with fewer than 20 articles per year at the beginning to a major research journal producing more than 160 articles per year. During the same time period, the field of landscape ecology has also developed tremendously from a newly revitalized conflation of ecology and geography to a fully-fledged interdisciplinary scientific enterprise that cuts across a wide range of natural and social sciences. Here I examine how the journal has grown during the 30 years between 1987 and 2016, with numbers and personal reflections. No, numbers cannot account for everything, but they do help us make better sense of changing patterns.

\section{A major milestone in the history of landscape ecology}

A scientific study is not completed before its results have been published in a peer-reviewed journal (Day and Gastel 2006). Before 1987, however, a landscape ecological study did not seem to fit any of the many ecology journals out there. "Scientifically, Landscape Ecology provided the first outlet for papers in this area, at a time when such papers were receiving resounding rejections from other mainstream journals in ecology" (Turner 2015, personal communication). Such situation may be common when a new field of study is emerging, but the field of landscape ecology had 


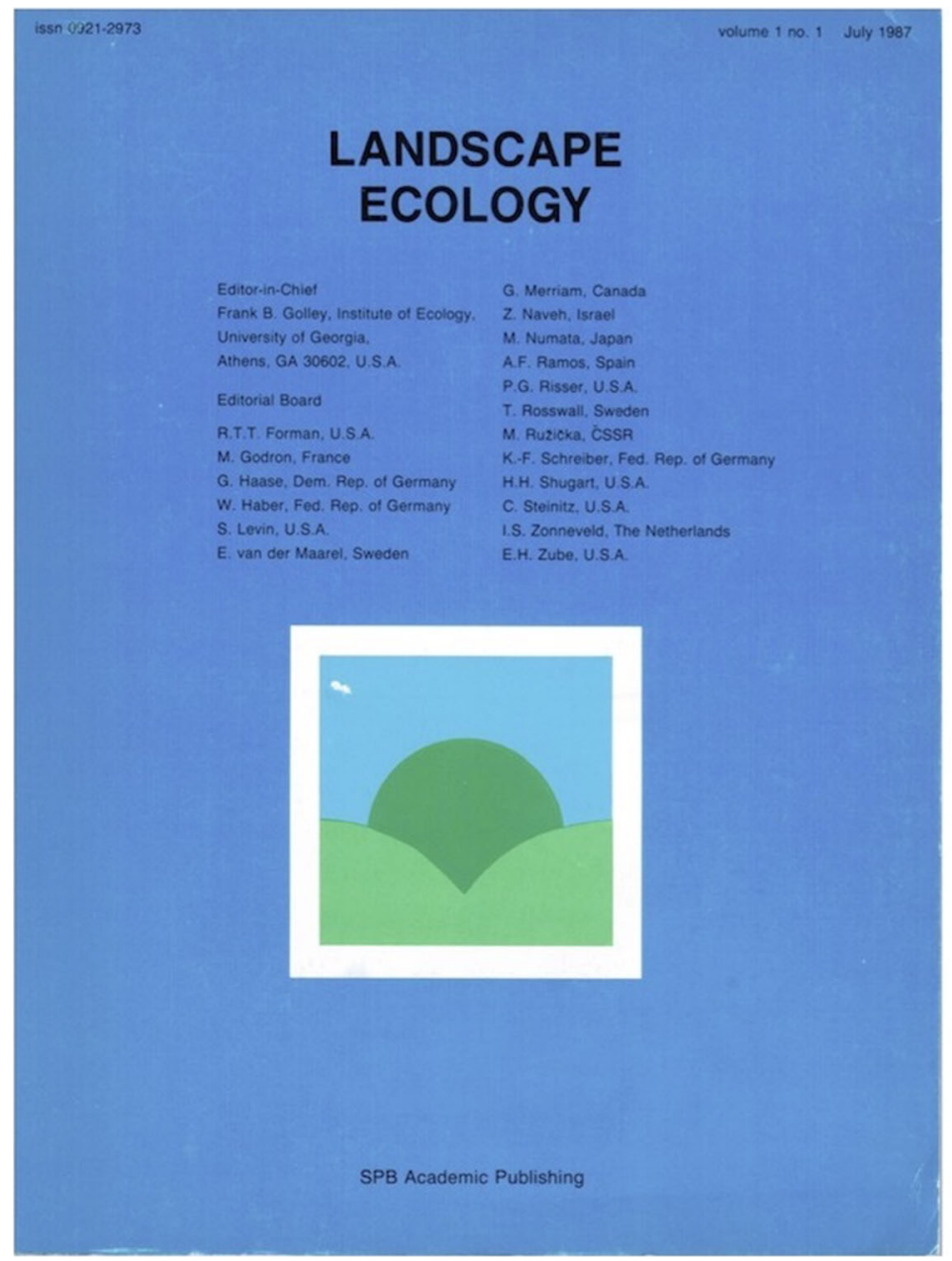

Editor-in-Chief: Frank B. Golley

\section{Editorial Board}

R.T.T. Forman, M. Godron, G. Haase, W. Haber, S. A. Levin, E. van der Maarel, G. Merriam, Z. Naveh, M. Numata, A. F. Ramos, P. G. Risser, R. Tosswall, M. Ruzicka, K.-F. Schreiber, H. H. Shugart, C. Steinitz, I. S. Zonneveld, E. H. Zube

\section{Table of Contents}

Introducing landscape ecology - Comments of the editor

Frank B. Golley

Creating landscape patterns by forest cutting:

Ecological consequences and principles

Jerry F. Franklin and Richard T. T. Forman

Neutral models for the analysis of broad-scale landscape pattern

Robert H. Gardner, Bruce T. Milne, Monica G.

Turner and Robert V. O'Neill

Spatial simulation of landscape changes in Georgia: A comparison of 3 transition models Monica G. Turner

Perceived land use patterns and landscape values Ervin H. Zube

Boundary dynamics at the aquatic-terrestrial interface: The influence of beaver and geomorphology

Carol A. Johnston and Robert J. Naiman

Effects of patch size, isolation and regional abundance on forest bird communities

D. van Dorp and P. F. M. Opdam

Fig. 1 The journal cover and table of contents of the inaugural issue of Landscape Ecology published by SPB Academic Publishing in July 1987

existed for 48 years by then. The rapid "globalization" of landscape ecology in the 1980s was facilitated by the dominant intellectual environment in ecology and technological advances at the time, eventually leading to the launching of the journal (Barrett et al. 2015; Forman 2015; Turner 2015; Wu 2015).

In a fascinating account of the historic events of landscape ecology, Forman (2015) identified several developmental periods: (1) "Early landscape ecology approaches in Europe (1938-1972)", (2) "Landscape ecology discovered in America (1972-1980)", (3) "Americans discover Europe, 'synergizing' landscape ecology (1981-1982)", and (4) "Coalescence of the field internationally and in America (1983-1987)", and (5) "Rapid growth phase (after 1987)". It is more than just a coincidence that the taking-off of the field of landscape ecology and the founding of the journal Landscape Ecology took place in the same time.

\section{The journal's growth by numbers}

Since 1987, Landscape Ecology has grown exponentially in terms of the numbers of published pages each year, leaping from 122 pages in 1987 to 2515 pages in 2016 (Fig. 2). The number of issues per year increased from four in 1987 to six in 1995, eight in 2000, ten in 2007, and twelve in 2017 (Fig. 2). Both the numbers of submitted and published manuscripts per year increased in a similar fashion, with the former 


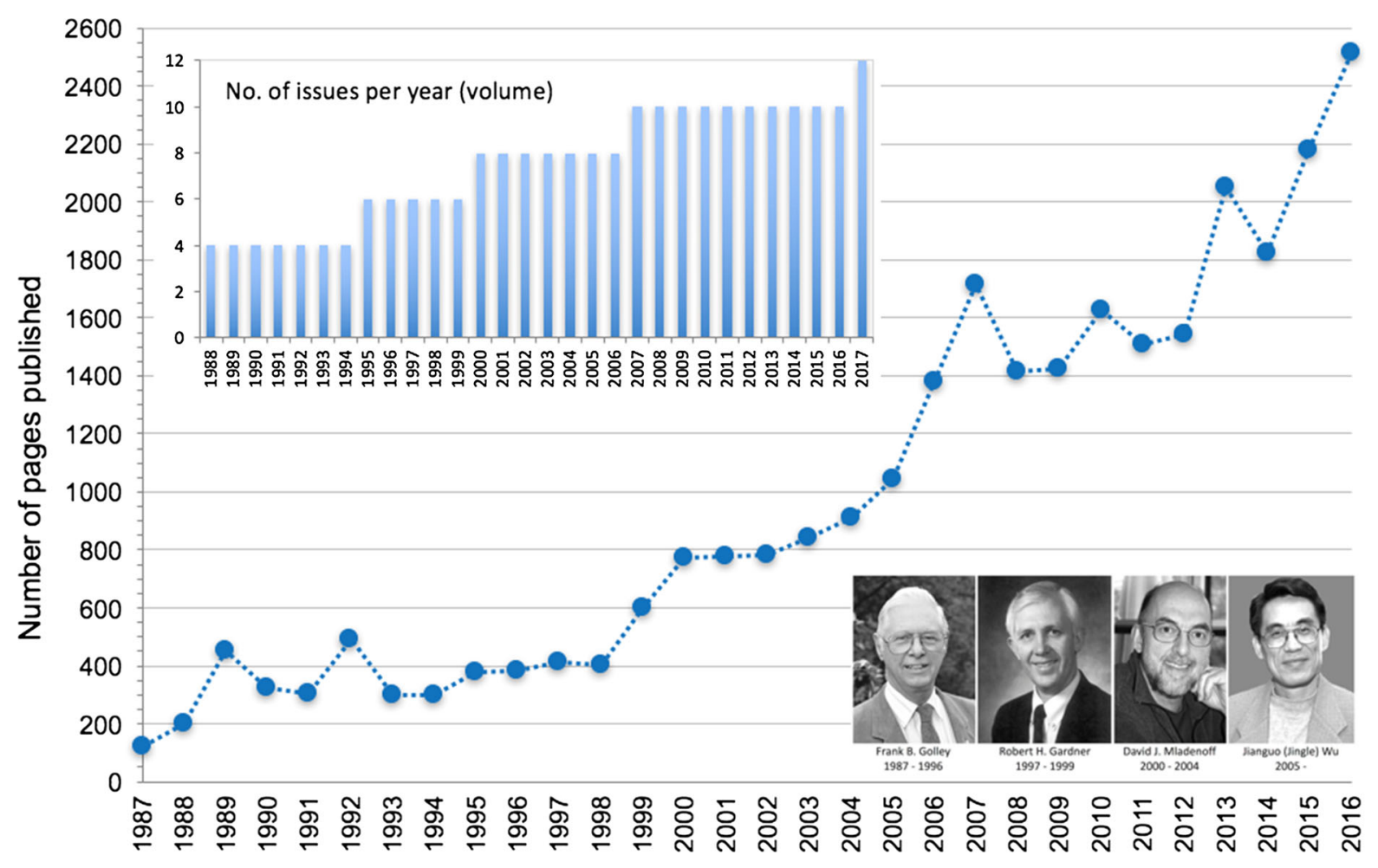

Fig. 2 Changes in the number of volumes per year (inset) and the total number of published pages per year for Landscape Ecology from 1987 to 2016. Shown at the bottom right corner

increasing much faster than the latter (Fig. 3). The total number of manuscript submissions was below 100 before 2000 , rose to roughly 200 by 2005 , and came close to 600 in 2016. The annual number of published articles varied between 20 and 50 from 1987 to 2004 , increased beyond 100 in 2006 , and surpassed 160 in 2016 (Fig. 3).

Landscape Ecology has had four Editors-in-Chief since its beginning. Frank Golley was succeeded by Robert Gardner in 1997, who was in turn replaced by David Mladenoff in 2000. Since 2005, Jianguo (Jingle) $\mathrm{Wu}$ has been the Editor-in-Chief of the journal. Golley and Gardner both made important contributions to the early development of landscape ecology in North America. In particular, Golley played an instrumental role in creating the journal. Mladenoff worked diligently for the journal for 5 years, improving the journal in a number of ways. While the first editorial board in 1987 consisted of 18 people from 10 countries, the 2016 editorial board consisted of more than 60 members from every are four Editors-in-Chief (left to right) during the past 30 years: Frank B. Golley, Robert H. Gardner, David J. Mladenoff, and Jianguo (Jingle) $\mathrm{Wu}$

continent. In addition to the editorial board, the advisory board of the journal was first established in 1998 , dissolved by the end of 1999 , and reestablished in 2007.

With the substantial increase in size, the journal's influence has also expanded rapidly. For example, the total number of citations to Landscape Ecology by other journals increased exponentially from 503 in 1997 to 7376 in 2016 (Fig. 4). The journal impact factor of Landscape Ecology has been increasing steadily since it acquired its first score of 1.3 in 1997, exceeding 2.0 in 2004, 3.0 in 2009, and 3.5 in 2013 (Fig. 4). Its overall ranking has been trending upward and consistently strong among hundreds of journals in ecological, environmental, and geographical sciences. According to InCites Journal Citation Reports, Landscape Ecology has been mostly within Quantile 1 since 2001 among journals of Physical Geography and Multidisciplinary Geosciences, and reached the Quantile 1 status of Ecology journals in 2009 (Fig. 4). 

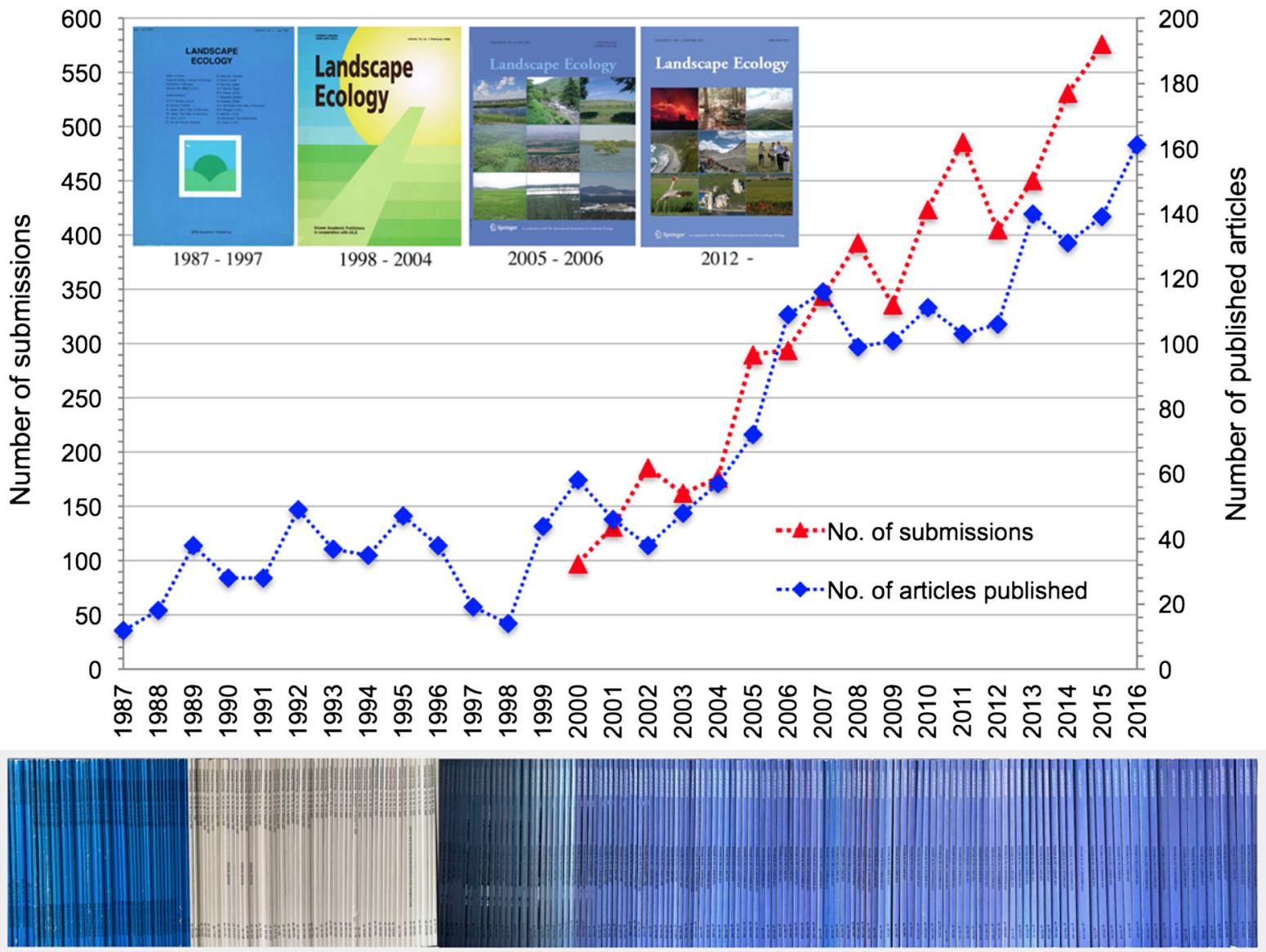

1987 --- 19971998 -------- 20042005

2016

Fig. 3 The numbers of submitted and published manuscripts per year for Landscape Ecology from 1987 to 2016 (data on accepted manuscripts before 2000 are not available). The inset

Figures 5 and 6 show the numbers of submitted and published papers for the top 30 countries during 2002-2016. In terms of the geographical origins of the authors, the overwhelming majority of submissions and accepted manuscripts to Landscape Ecology during 2002-2016 came from Norther America and Europe (Fig. 5). The United States alone accounted about $30 \%$ of the total submissions, with the highest acceptance rate. United States, Canada, Australia, China, Germany, France, the Netherlands, UK, Spain, and Brazil were all major contributors to the published papers in the journal, although China and Spain had a substantially lower acceptance rate than the other leading countries (Figs. 5, 6). Given the history and recent developments of landscape ecology, it is not photos are the four journal cover designs during the 30 years. The bottom photo shows all the printed issues from 1987 to 2016

surprising to see this dominance by North America and Europe. However, we should be aware that this apparent geographic imbalance is, to some extent, reflective of the uneven development of the science. It is encouraging that this geographic imbalance seems to decline in recent years.

\section{Top 30 most cited papers in the past 30 years}

The top 30 most cited papers published in Landscape Ecology during the 30 years (Table 1) seem to capture some of the key topics in the field: landscape pattern analysis, land use/land cover change, landscape disturbance dynamics, landscape pattern quantification 
and interpretation, scale effects and scaling, neutral landscape models and critical thresholds, landscape connectivity measures, and ecological effects of landscape fragmentation. In the first decade of the journal, relatively more papers dealt with conceptual issues and landscape pattern analysis. Since the beginning of the second decade, purely descriptive studies have decreased in number. On the topics of land use change and landscape fragmentation, increasing emphasis has been placed on the driving processes and impacts on ecosystem processes and ecosystem services. Patterns, processes, and environmental consequences of urbanization have become increasingly dominant in the journal pages since the late 1990s.

Several classic papers in landscape ecology published between the late 1980s and the mid-1990s by leading scientists-e.g., Richard Forman, Jerry Franklin, Robert Gardner, Robert O'Neill, Paul Opdam, Kurt Riitters, Monica Turner, and John Wiens-have continued to influence the development of the field, with persistently high citation rates (Table 1). Most landscape ecological studies have been carried out on broad scales-hundreds to thousands of square kilometers in area-although the essential ideas of landscape ecology can be applied essentially to any scale. With increasing needs for scaling up ecological information and for integrating human and environmental systems, several papers on scale and scaling issues are among the top 30 most cited papers. In terms of ecosystem or landscape types studied, forests and urban areas appear to be the most studied landscapes, but an increasing number of published papers also

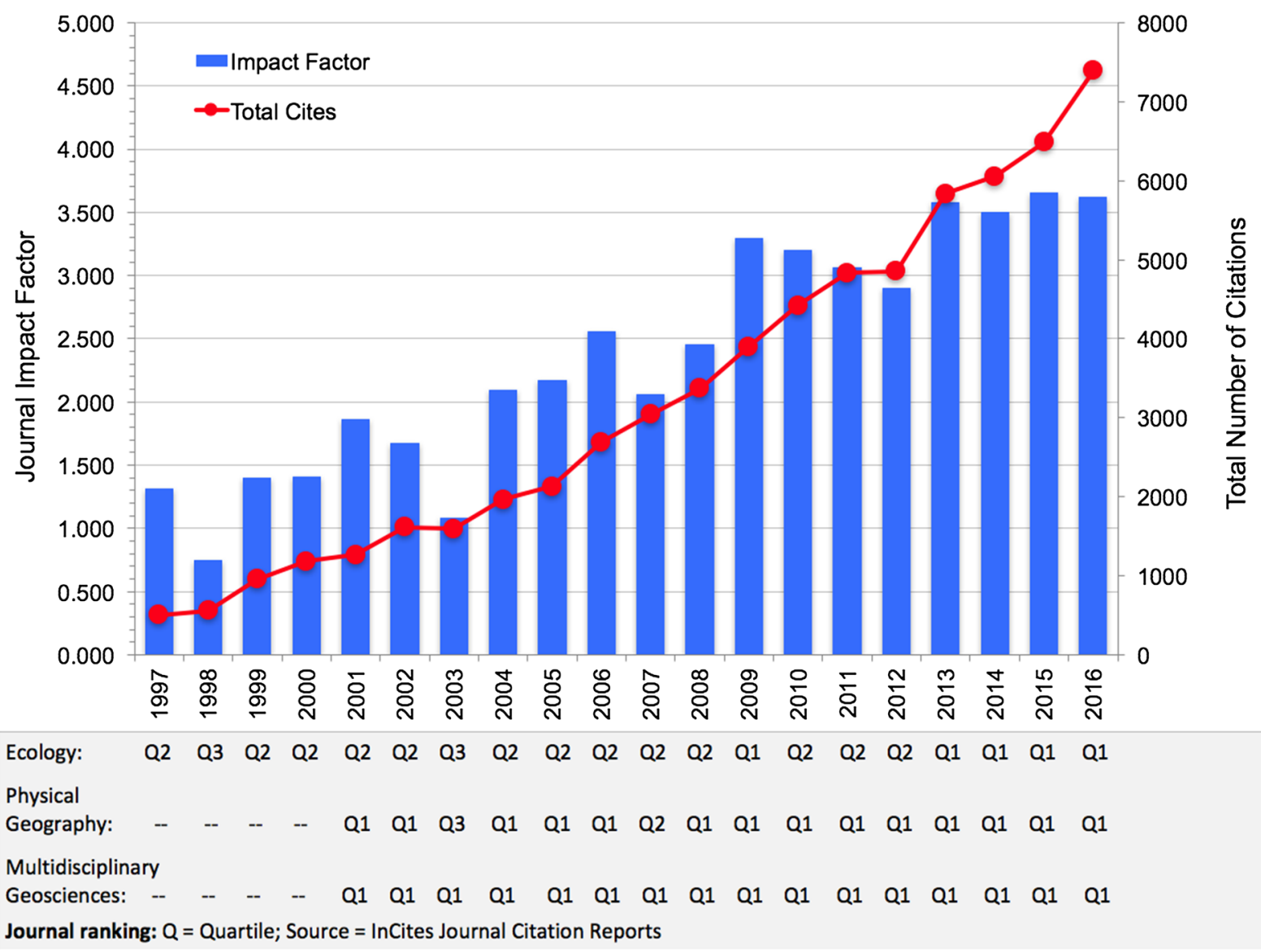

Fig. 4 The total number of citations to papers published in Landscape Ecology and the journal impact factor since 1997 when it first appeared. The bottom table shows the journal's rankings in ecology, physical geography, and multidisciplinary geosciences from 1997 to 2016 (data from InCites Journal Citation Reports) 
(A)

2002-2006

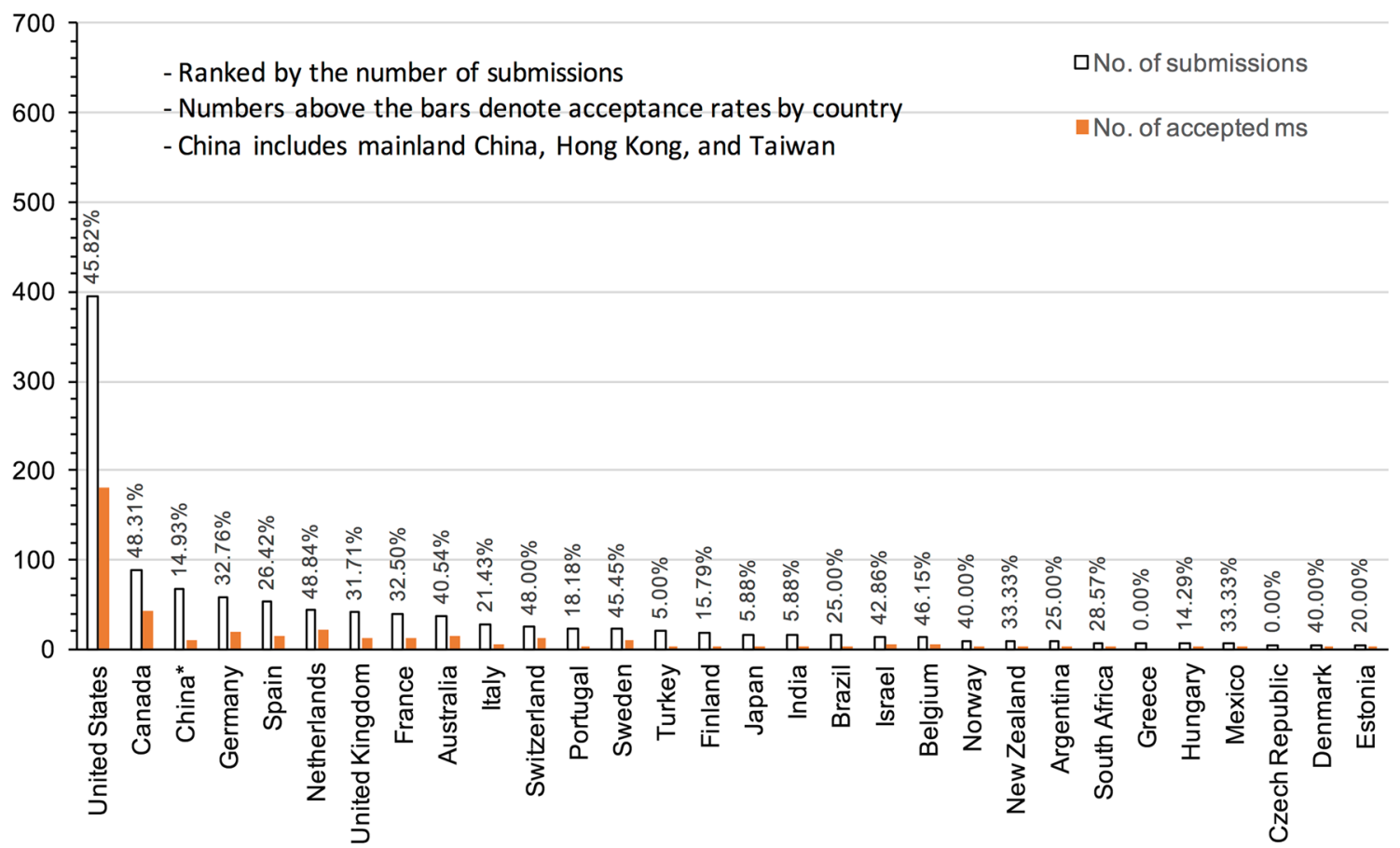

(B) 2007-2011

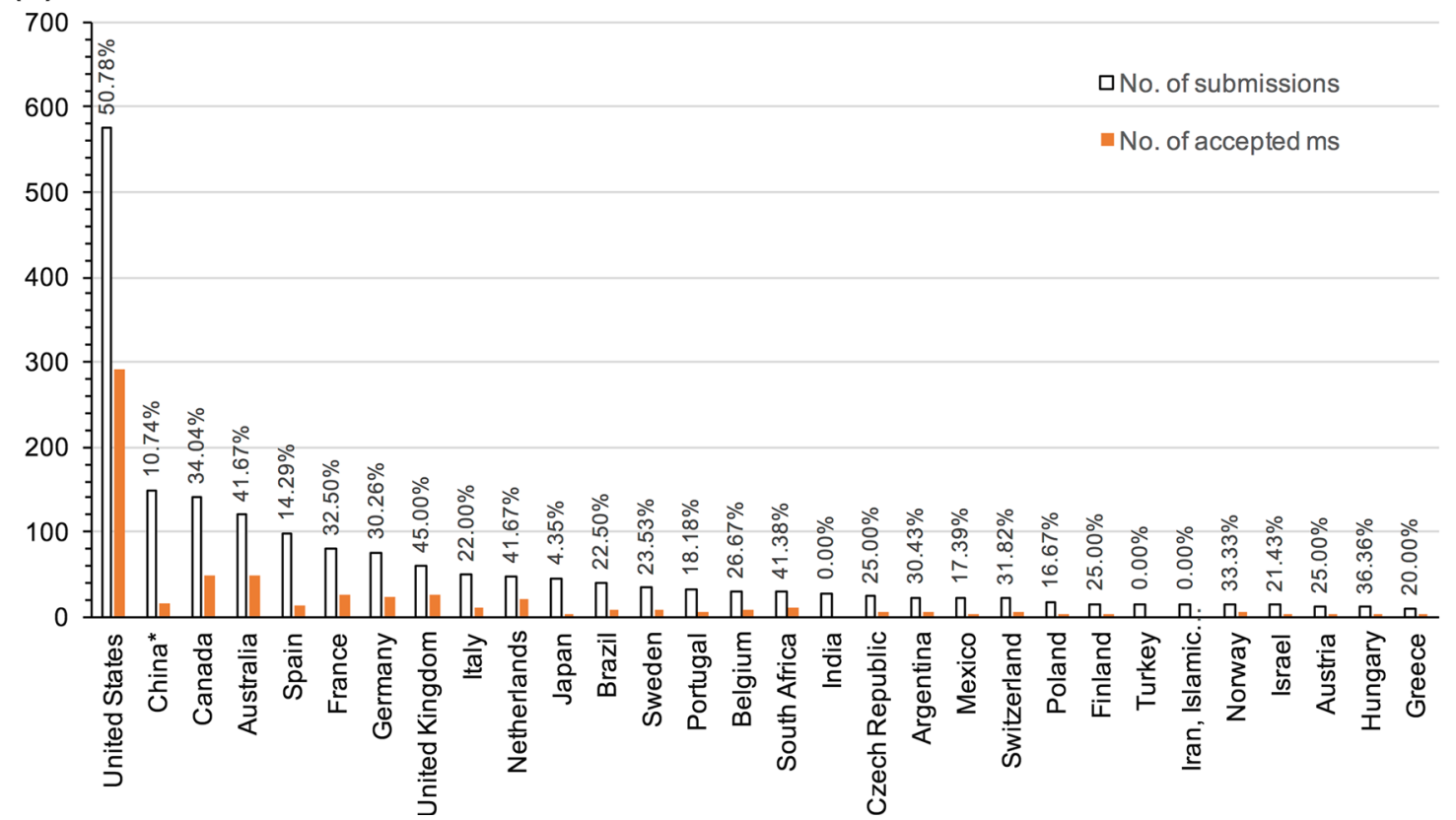

Fig. 5 Numbers of submitted and accepted manuscripts in Landscape Ecology for the top 30 countries during 15 years between 2002 and 2016 (data from the journal's Editorial Manager system; no data available before 2002). a, b, and c show the distribution pattern of the three 5-year periods, and D is for the 15-year duration. Countries are ranked by the number of submissions in a descending order, with country-specific acceptance rates shown above the bars 


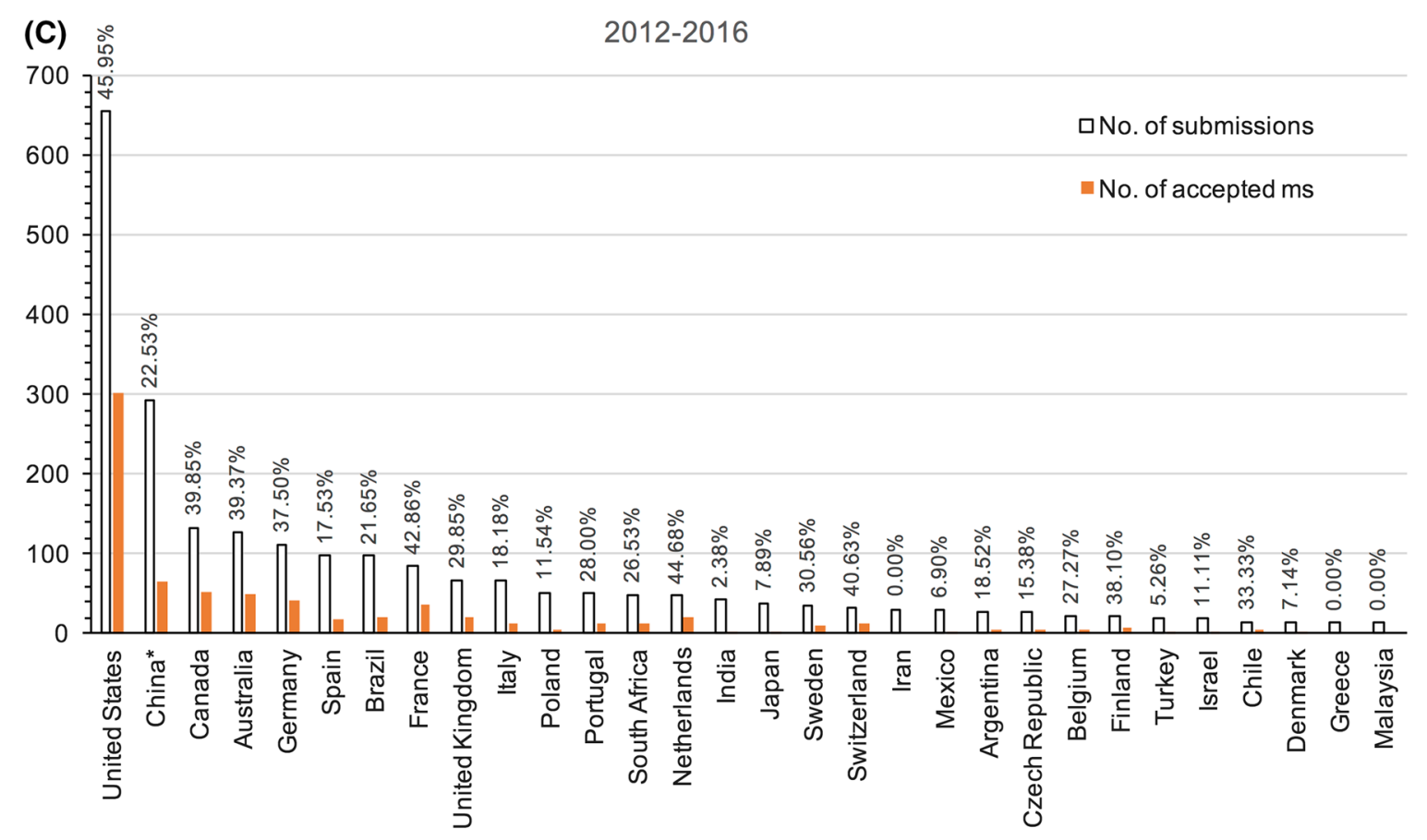

(D)

1800

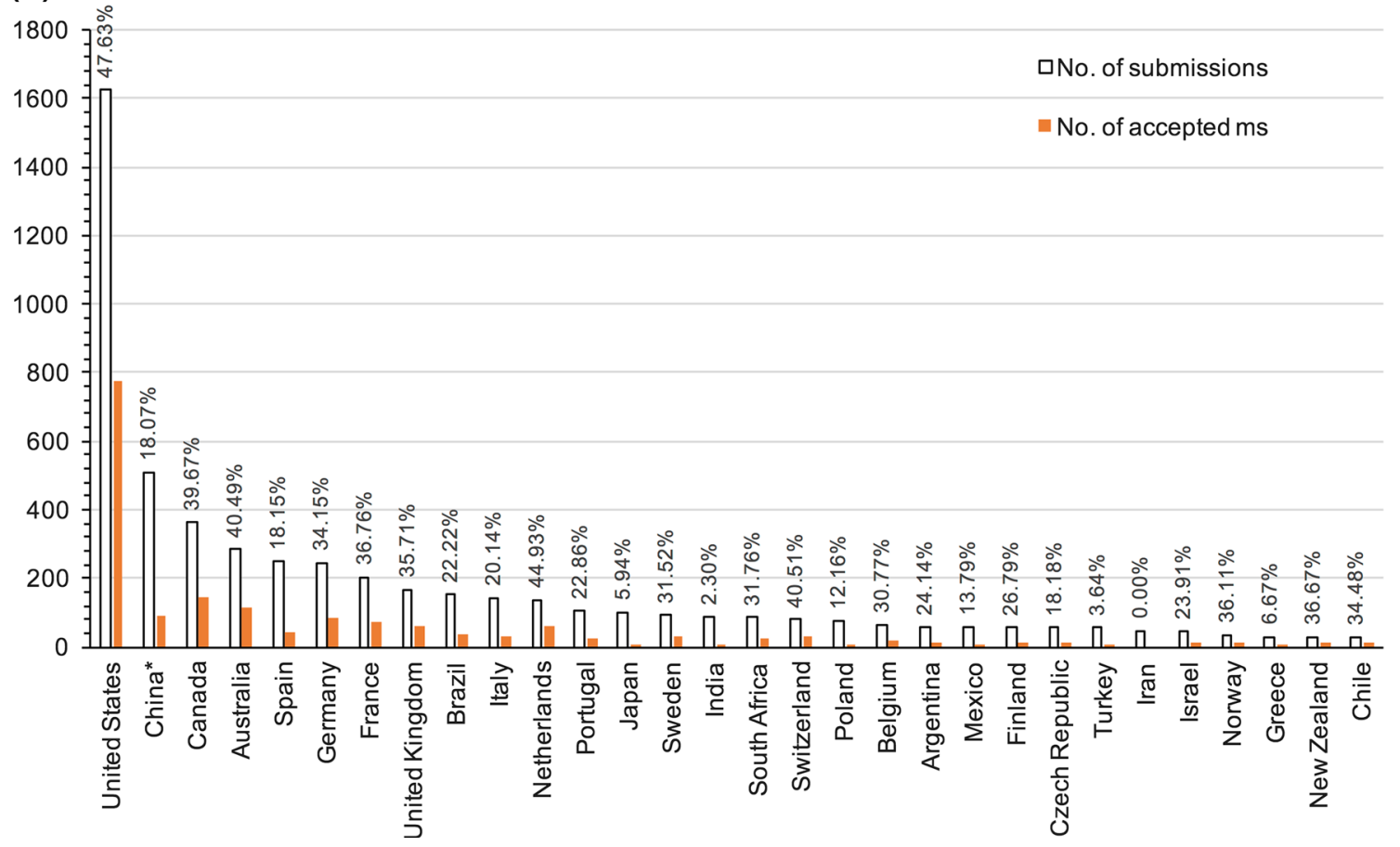

Fig. 5 continued 

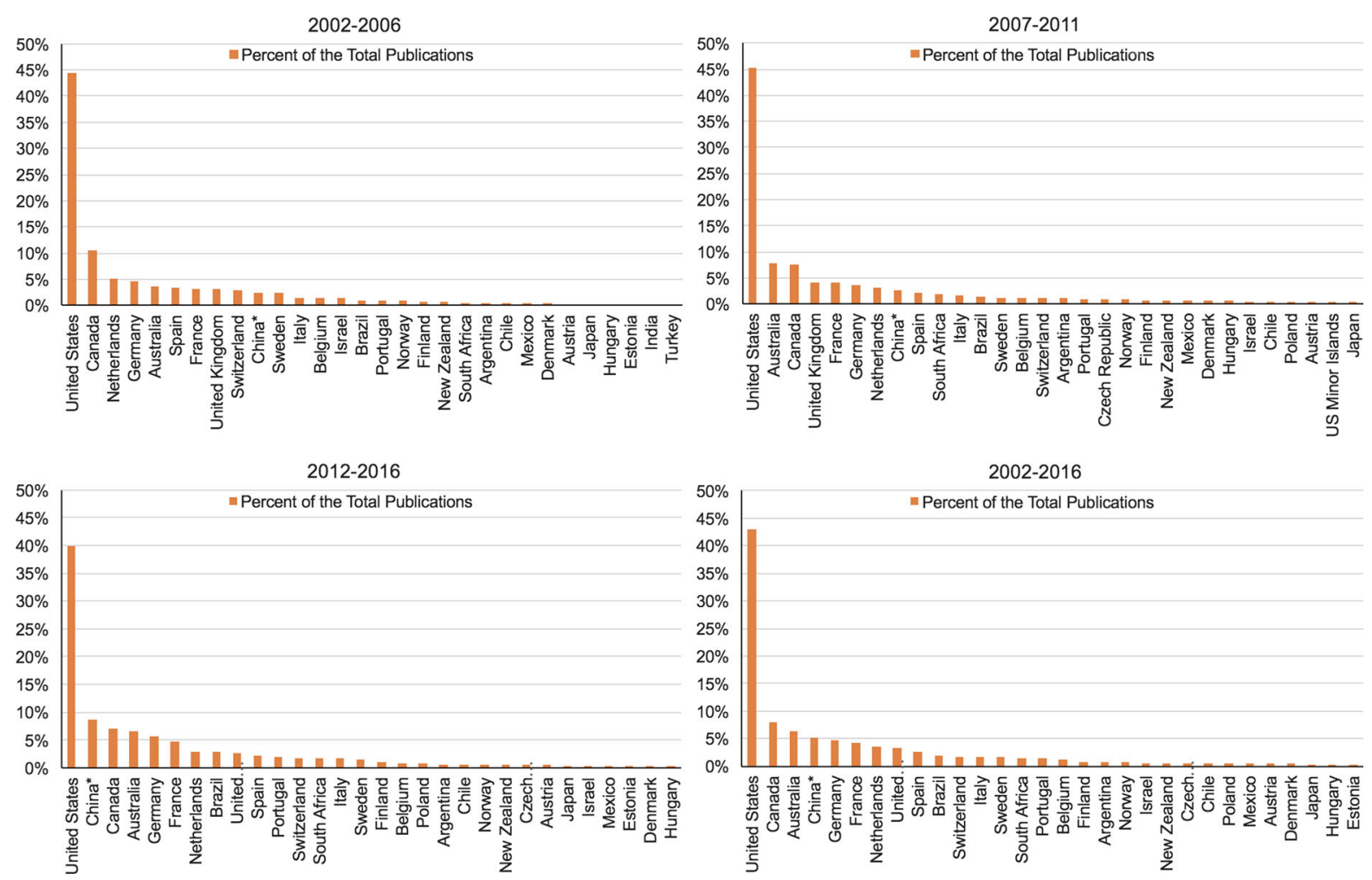

Fig. 6 Articles published in Landscape Ecology between 2002 and 2016 for the top 30 countries (data from the journal's Editorial Manager system; no data available before 2002). Patterns for each 5-year segment and the entire 15-year period

are shown. Countries are ranked by their percent contributions to the total publications of the journal during the corresponding time period

focus on deserts and grasslands. Landscape ecological studies have relied heavily on the use of remote sensing data and GIS, and multiple-scale approaches have become the norm in data acquisition and analysis.

The most cited papers during the most recent decade (2006-2016) suggest several currently "hot" and "attractive" topics (Table 2). Landscape genetics has become one of the most rapidly developing areas in landscape ecology, which integrates landscape pattern analysis with population genetics. Urban landscape ecology is gaining momentum worldwide, and landscape modeling is becoming more diverse in kind and more capable of simulating human-environmental interactions and assisting decision making. The studies of ecosystem services in changing landscapes, as well as landscape services, have been proliferating. Related to this is the topic of landscape sustainability and landscape resilience which has received increasing attention from landscape ecologists worldwide. In

addition, with increasing interactions between landscape ecologists and land designers and planners, the papers by leading scholars such as Joan Nassauer and Paul Opdam on integrating design and culture with landscape ecology have been gaining a great deal of attention (Table 2).

\section{Landscape ecology beyond Landscape Ecology}

As mentioned before, few landscape ecological studies were published in SCI journals before the founding of the journal, Landscape Ecology. Has this situation changed during the past 30 years? Our literature search using Web of Science reveals that the number of papers on landscape ecology published in all other SCI journals increased from 20 in 1987 to 2302 in 2016, with a total of 21,896 articles (Fig. 7). During the past 30 years, the number of papers published in the journal, Landscape Ecology, and all other SCI 
Table 1 The top 30 most cited papers published in Landscape Ecology during its first 30 years from 1987 to 2016 , based on data from Web of Science Core Collection (accessed on Nov. 7, 2017)

\begin{tabular}{|c|c|c|c|}
\hline Order & Publication & Total cites & Cites/year \\
\hline 1 & $\begin{array}{l}\text { O’Neill, R. V., J. R. Krummel, R. H. Gardner, G. Sugihara, B. Jackson, D. } \\
\text { L. DeAngelis, B. T. Milne, M. G. Turner, B. Zygmunt, S. W. Christensen, V. H. Dale, } \\
\text { and R. L. Graham. 1988. Indices of landscape pattern. Landscape Ecol 1:153-162 }\end{array}$ & 793 & 26.4 \\
\hline 2 & $\begin{array}{l}\text { Riitters, K. H., R. V. Oneill, C. T. Hunsaker, J. D. Wickham, D. H. Yankee, S. } \\
\text { P. Timmins, K. B. Jones, and B. L. Jackson. 1995. A factor analysis of landscape } \\
\text { pattern and structure metrics. Landscape Ecol 10:23-39 }\end{array}$ & 568 & 24.7 \\
\hline 3 & $\begin{array}{l}\text { Franklin, J. F., and R. T. T. Forman. 1987. Creating landscape patterns by forest cutting: } \\
\text { Ecological consequences and principles. Landscape Ecol 1:5-18 }\end{array}$ & 531 & 17.1 \\
\hline 4 & $\begin{array}{l}\text { Turner, M. G., R. V. O'Neill, R. H. Gardner, and B. T. Milne. 1989. Effects of changing } \\
\text { spatial scale on the analysis of landscape pattern. Landscape Ecol 3:153-162 }\end{array}$ & 489 & 16.9 \\
\hline 5 & $\begin{array}{l}\text { Roth, N. E., J. D. Allan, and D. L. Erickson. 1996. Landscape influences on stream } \\
\text { biotic integrity assessed at multiple spatial scales. Landscape Ecol 11:141-156 }\end{array}$ & 486 & 22.1 \\
\hline 6 & $\begin{array}{l}\text { Gardner, R. H., B. T. Milne, M. G. Turner, and R. V. O'Neill. 1987. Neutral models for } \\
\text { the analysis of broad-scale landscape pattern. Landscape Ecol 1:19-28 }\end{array}$ & 423 & 13.7 \\
\hline 7 & $\begin{array}{l}\text { Wu, J. G. 2004. Effects of changing scale on landscape pattern analysis: Scaling } \\
\text { relations. Landscape Ecol 19:125-138 }\end{array}$ & 417 & 29.8 \\
\hline 8 & $\begin{array}{l}\text { Wu, J. G., and R. Hobbs. 2002. Key issues and research priorities in landscape ecology: } \\
\text { An idiosyncratic synthesis. Landscape Ecol 17:355-365 }\end{array}$ & 397 & 24.8 \\
\hline 9 & $\begin{array}{l}\text { Li, H. B., and J. G. Wu. 2004. Use and misuse of landscape indices. Landscape Ecol } \\
\text { 19:389-399 }\end{array}$ & 359 & 25.6 \\
\hline 10 & $\begin{array}{l}\text { Luck, M., and J. G. Wu. 2002. A gradient analysis of urban landscape pattern: A case } \\
\text { study from the Phoenix metropolitan region, Arizona, USA. Landscape Ecol } \\
\text { 17:327-339 }\end{array}$ & 352 & 22.0 \\
\hline 11 & $\begin{array}{l}\text { Hargis, C. D., J. A. Bissonette, and J. L. David. 1998. The behavior of landscape } \\
\text { metrics commonly used in the study of habitat fragmentation. Landscape Ecol } \\
\text { 13:167-186 }\end{array}$ & 349 & 17.5 \\
\hline 12 & $\begin{array}{l}\text { Turner, M. G., and W. H. Romme. 1994. Landscape dynamics in crown fire ecosystems. } \\
\text { Landscape Ecol 9:59-77 }\end{array}$ & 335 & 14.0 \\
\hline 13 & $\begin{array}{l}\text { Jaeger, J. A. G. 2000. Landscape division, splitting index, and effective mesh size: new } \\
\text { measures of landscape fragmentation. Landscape Ecol 15:115-130 }\end{array}$ & 314 & 17.4 \\
\hline 14 & $\begin{array}{l}\text { Forman, R. T. T. 1995. Some general principles of landscape and regional ecology. } \\
\text { Landscape Ecol 10:133-142 }\end{array}$ & 302 & 13.1 \\
\hline 15 & $\begin{array}{l}\text { Jelinski, D. E., and J. G. Wu. 1996. The modifiable areal unit problem and implications } \\
\text { for landscape ecology. Landscape Ecol 11:129-140 }\end{array}$ & 298 & 13.6 \\
\hline 16 & $\begin{array}{l}\text { Gustafson, E. J., and G. R. Parker. 1992. Relationships between landcover proportion } \\
\text { and indices of landscape spatial pattern. Landscape Ecol 7:101-110 }\end{array}$ & 298 & 11.5 \\
\hline 17 & $\begin{array}{l}\text { Matthews, R. B., N. G. Gilbert, A. Roach, J. G. Polhill, and N. M. Gotts. 2007. Agent- } \\
\text { based land-use models: A review of applications. Landscape Ecol 22:1447-1459 }\end{array}$ & 295 & 26.8 \\
\hline 18 & $\begin{array}{l}\text { Andow, D. A., P. M. Kareiva, S. A. Levin, and A. Okubo. 1990. Spread of invading } \\
\text { organisms. Landscape Ecol 4:177-188 }\end{array}$ & 292 & 10.4 \\
\hline 19 & $\begin{array}{l}\text { Turner, M. G. 1990. Spatial and temporal analysis of landscape patterns. Landscape } \\
\text { Ecol 4:21-30 }\end{array}$ & 289 & 10.3 \\
\hline 20 & $\begin{array}{l}\text { Burgi, M., A. M. Hersperger, and N. Schneeberger. 2004. Driving forces of landscape } \\
\text { change - current and new directions. Landscape Ecol 19:857-868 }\end{array}$ & 273 & 19.5 \\
\hline 21 & $\begin{array}{l}\text { Gobster, P. H., J. I. Nassauer, T. C. Daniel, and G. Fry. 2007. The shared landscape: } \\
\text { what does aesthetics have to do with ecology? Landscape Ecol 22:959-972 }\end{array}$ & 269 & 24.5 \\
\hline 22 & $\begin{array}{l}\text { Seto, K. C., and M. Fragkias. 2005. Quantifying spatiotemporal patterns of urban land- } \\
\text { use change in four cities of China with time series landscape metrics. Landscape Ecol } \\
\text { 20:871-888 }\end{array}$ & 269 & 20.7 \\
\hline
\end{tabular}


Table 1 continued

\begin{tabular}{|c|c|c|c|}
\hline Order & Publication & Total cites & Cites/year \\
\hline 23 & $\begin{array}{l}\text { Wiens, J. A., and B. T. Milne. 1989. Scaling of 'landscape' in landscape ecology, or, } \\
\text { landscape ecology from a beetle's perspective. Landscape Ecol 3:87-96 }\end{array}$ & 262 & 9.0 \\
\hline 24 & $\begin{array}{l}\text { Falcucci, A., L. Maiorano, and L. Boitani. 2007. Changes in land-use/land-cover } \\
\text { patterns in Italy and their implications for biodiversity conservation Landscape Ecol } \\
22: 617-631\end{array}$ & 257 & 23.4 \\
\hline 25 & $\begin{array}{l}\text { Wu, J., W. J. Shen, W. Z. Sun, and P. T. Tueller. 2002. Empirical patterns of the effects } \\
\text { of changing scale on landscape metrics. Landscape Ecol 17:761-782 }\end{array}$ & 249 & 15.6 \\
\hline 26 & $\begin{array}{l}\text { Turner, M. G., W. H. Romme, R. H. Gardner, R. V. Oneill, and T. K. Kratz. 1993. A } \\
\text { revised concept of landscape equilibrium - disturbance and stability on scaled } \\
\text { landscapes. Landscape Ecol 8:213-227 }\end{array}$ & 248 & 9.9 \\
\hline 27 & $\begin{array}{l}\text { Plotnick, R. E., R. H. Gardner, and R. V. Oneill. 1993. Lacunarity indexes as measures } \\
\text { of landscape texture. Landscape Ecol 8:201-211 }\end{array}$ & 245 & 9.8 \\
\hline 28 & $\begin{array}{l}\text { Ludwig, J. A., and D. J. Tongway. 1995. Spatial-organization of landscapes and its } \\
\text { function in semiarid woodlands, Australia. Landscape Ecol 10:51-63 }\end{array}$ & 243 & 10.6 \\
\hline 29 & $\begin{array}{l}\text { Baguette, M., and H. Van Dyck. 2007. Landscape connectivity and animal behavior: } \\
\text { functional grain as a key determinant for dispersal. Landscape Ecol 22:1117-1129 }\end{array}$ & 237 & 21.6 \\
\hline 30 & $\begin{array}{l}\text { van Dorp, D., and P. F. M. Opdam. 1987. Effects of patch size, isolation and regional } \\
\text { abundance on forest bird communities. Landscape Ecol 1:59-73 }\end{array}$ & 230 & 7.4 \\
\hline
\end{tabular}

journals both increased exponentially, but the latter was 10.3 times more than the former by 2016 (Fig. 7). These numbers clearly indicate that landscape ecology has been developing rather rapidly as a field of study, with its ideas and methods penetrating into a number of other fields across ecological, geographical, and environmental sciences. In fact, spatial heterogeneity and scale became a dominant theme in ecology by the 1990s. The paper by Simon Levin (1992) published in Ecology, "The problem of pattern and scale in ecology", was the most highly cited paper in the entire field of ecology in the 1990s (cited 3473 times as per Web of Science Core Collections as of Nov. 7, 2017). The review paper on landscape ecology by Monica Turner (1989) in Annual Review of Ecology and Evolution has also been widely influential in both ecological and geographical sciences (cited 1494 times as per Web of Science Core Collections as of Nov. 7, 2017).

Top 10 journals with most published articles on landscape ecology between 1987 and 2016 are: Landscape and Urban Planning, Biological Conservation, Forest Ecology and Management, PLOS One, Ecological Applications, Ecological Modelling, Ecology, Biodiversity and Conservation, Ecological Indicators, and Journal of Applied Ecology. These data indicate that landscape ecological studies are now well represented in mainstream journals in ecology, conservation, and landscape planning and design (Fig. 8). Top 10 countries with most published articles on landscape ecology in SCI journals between 1987 and 2016 are USA (9735), Australia (2042), Canada (1998), UK (1775), Germany (1487), France (1355), China (1351), Spain (1100), Italy (881), and Brazil (835). While the dominance of landscape ecological publications by the United States was evident and overwhelming, the annual output of each country all increased exponentially during the 30 years, most noticeably for China (Fig. 9). For all the top 10 countries, the rate of increase in publications seemed to accelerate since around 2006, which coincided well with the rapid increase in the number of published articles in the journal, Landscape Ecology (Figs. 2, 3).

\section{Concluding remarks}

The process of scientific publishing has been essential to the advancement of science. As the flagship journal of the international association for the field, Landscape Ecology has served the scientific community well for 30 years. The journal is an important 
Table 2 The top 30 most cited papers published in Landscape Ecology during 2006-2016, based on Web of Science Core Collection (accessed on Nov. 7, 2017)

\begin{tabular}{|c|c|c|c|c|c|c|c|c|}
\hline Title & Authors & $\begin{array}{l}\text { Publication } \\
\text { year }\end{array}$ & Volume & Issue & $\begin{array}{l}\text { Beginning } \\
\text { page }\end{array}$ & $\begin{array}{l}\text { Ending } \\
\text { page }\end{array}$ & $\begin{array}{l}\text { Total } \\
\text { citations }\end{array}$ & $\begin{array}{l}\text { Aveage } \\
\text { per year }\end{array}$ \\
\hline $\begin{array}{l}\text { Estimating landscape resistance } \\
\text { to movement a review }\end{array}$ & $\begin{array}{l}\text { Zeller. Katherine A; } \\
\text { McGarigal, Kevin; } \\
\text { Whiteley, Andrew } \\
\text { R. }\end{array}$ & 2012 & 27 & 6 & 777 & 797 & 202 & 33.7 \\
\hline $\begin{array}{l}\text { Landscape sustainability } \\
\text { science: ecosystem services } \\
\text { and human well-being in } \\
\text { changing landscapes }\end{array}$ & Wu, Jianguo & 2013 & 28 & 6 & 999 & 1023 & 159 & 31.8 \\
\hline $\begin{array}{l}\text { Agent-based land-use models: a } \\
\text { review of applications }\end{array}$ & $\begin{array}{l}\text { Matthews, Robin B.; } \\
\text { Gilbert, Nigel G.; } \\
\text { Roach, Alan; } \\
\text { Polhill, J. Gary; } \\
\text { Gotts, Nick M. }\end{array}$ & 2007 & 22 & 10 & 1447 & 1459 & 295 & 26.8 \\
\hline $\begin{array}{l}\text { Wetlands, carbon, and climate } \\
\text { change }\end{array}$ & $\begin{array}{l}\text { Mitsch, William J.; } \\
\text { Bernal, Blanca; } \\
\text { Nahlik, Amanda M. } \\
\text { et al. }\end{array}$ & 2013 & 28 & 4 & 583 & 597 & 128 & 25.6 \\
\hline $\begin{array}{l}\text { The shared landscape: what } \\
\text { does aesthetics have to do } \\
\text { with ecology? }\end{array}$ & $\begin{array}{l}\text { Gobster, Paul H.; } \\
\text { Nassauer, Joan I.; } \\
\text { Daniel, Terry C.; } \\
\text { Fry, Gary }\end{array}$ & 2007 & 22 & 7 & 959 & 972 & 269 & 24.5 \\
\hline $\begin{array}{l}\text { Changes in land-use/land-cover } \\
\text { patterns in Italy and their } \\
\text { implications for biodiversity } \\
\text { conservation }\end{array}$ & $\begin{array}{l}\text { Falcucci, Alessandra; } \\
\text { Maiorano, Luigi; } \\
\text { Boitoni, Luigi }\end{array}$ & 2007 & 22 & 4 & 617 & 631 & 257 & 23.4 \\
\hline $\begin{array}{l}\text { Combining top-down and } \\
\text { bottom-up dynamics in land } \\
\text { use modeling: exploring the } \\
\text { future of abandoned farmlands } \\
\text { in Europe with the Dyna- } \\
\text { CLUE model }\end{array}$ & $\begin{array}{l}\text { Verburg, Peter H.; } \\
\text { Overmars, Keen P. }\end{array}$ & 2009 & 24 & 9 & 1167 & 1181 & 210 & 23.3 \\
\hline $\begin{array}{l}\text { Landscape connectivity and } \\
\text { animal behavior functional } \\
\text { grain as a key determinant for } \\
\text { dispersal }\end{array}$ & $\begin{array}{l}\text { Baguette, Michel; } \\
\text { Van Dyck, Hans }\end{array}$ & 2007 & 22 & 8 & 1117 & 1129 & 237 & 21.6 \\
\hline $\begin{array}{l}\text { Modeling population } \\
\text { connectivity by ocean } \\
\text { currents, a graph-theoretic } \\
\text { approach for marine } \\
\text { conservation }\end{array}$ & $\begin{array}{l}\text { Treml, Eric A; } \\
\text { Halpin, Patrick N.; } \\
\text { Urban, Dean L.; } \\
\text { Pratson, Lincoln F. }\end{array}$ & 2008 & 23 & S & 19 & 36 & 207 & 20.7 \\
\hline $\begin{array}{l}\text { Urban heat islands and } \\
\text { landscape heterogeneity } \\
\text { linking spatiotemporal } \\
\text { variations in surface } \\
\text { temperatures to land-cover } \\
\text { and socioeconomic patterns }\end{array}$ & $\begin{array}{l}\text { Buyantuyev, } \\
\text { Alexander, Wu, } \\
\text { Jianguo }\end{array}$ & 2010 & 25 & 1 & 17 & 33 & 163 & 20.4 \\
\hline $\begin{array}{l}\text { Landscape services as a bridge } \\
\text { between landscape ecology } \\
\text { and sustainable development }\end{array}$ & $\begin{array}{l}\text { Termorshuizen, } \\
\text { Jolande W.; Opdam, } \\
\text { Paul }\end{array}$ & 2009 & 24 & 8 & 1037 & 1052 & 171 & 19.0 \\
\hline $\begin{array}{l}\text { Comparison and development of } \\
\text { new graph-based landscape } \\
\text { connectivity indices: towards } \\
\text { the priorization of habitat } \\
\text { patches and corridors for } \\
\text { conservation }\end{array}$ & $\begin{array}{l}\text { Pascual-Hortal, Lucia; } \\
\text { Saura, Santiago }\end{array}$ & 2006 & 21 & 7 & 959 & 967 & 224 & 18.7 \\
\hline
\end{tabular}


Table 2 continued

\begin{tabular}{|c|c|c|c|c|c|c|c|c|}
\hline Title & Authors & $\begin{array}{l}\text { Publication } \\
\text { year }\end{array}$ & Volume & Issue & $\begin{array}{l}\text { Beginning } \\
\text { page }\end{array}$ & $\begin{array}{l}\text { Ending } \\
\text { page }\end{array}$ & $\begin{array}{l}\text { Total } \\
\text { citations }\end{array}$ & $\begin{array}{l}\text { Aveage } \\
\text { per year }\end{array}$ \\
\hline $\begin{array}{l}\text { The use of gradient analysis } \\
\text { studies in advancing our } \\
\text { understanding of the ecology } \\
\text { of urbanizing landscapes: } \\
\text { current status and future } \\
\text { directions }\end{array}$ & $\begin{array}{l}\text { McDonnell, Mark J.; } \\
\text { Hahs, Amy K. }\end{array}$ & 2008 & 23 & 10 & 1143 & 1155 & 183 & 18.3 \\
\hline Connectivity measures: a review & $\begin{array}{l}\text { Kindlmann, Pavel; } \\
\text { Burel, Francoise }\end{array}$ & 2008 & 23 & 8 & 879 & 890 & 162 & 16.2 \\
\hline $\begin{array}{l}\text { Confronting collinearity: } \\
\text { comparing methods for } \\
\text { disentangling the effects of } \\
\text { habitat loss and fragmentation }\end{array}$ & $\begin{array}{l}\text { Smith, Adam C.; } \\
\text { Koper, Nicola; } \\
\text { Francis, Charles M.; } \\
\text { Fahrig, Lenore }\end{array}$ & 2009 & 24 & 10 & 1271 & 1285 & 143 & 15.9 \\
\hline $\begin{array}{l}\text { Genetic analysis of landscape } \\
\text { connectivity in tree } \\
\text { populations }\end{array}$ & $\begin{array}{l}\text { Sork, Victoria L.; } \\
\text { Smouse, Peter E. }\end{array}$ & 2006 & 21 & 6 & 821 & 836 & 176 & 14.7 \\
\hline $\begin{array}{l}\text { Design in science: extending the } \\
\text { landscape ecology paradigm }\end{array}$ & $\begin{array}{l}\text { Nassauer, Joan } \\
\text { Iverson; Opdam, } \\
\text { Paul }\end{array}$ & 2008 & 23 & 6 & 633 & 644 & 144 & 14.4 \\
\hline $\begin{array}{l}\text { Regional relationships between } \\
\text { surface temperature, } \\
\text { vegetation, and human } \\
\text { settlement in a rapidly } \\
\text { urbanizing ecosystem }\end{array}$ & $\begin{array}{l}\text { Jenerette, G. Darrel; } \\
\text { Harlan, Sharon L. } \\
\text { et al. }\end{array}$ & 2007 & 22 & 3 & 353 & 365 & 155 & 14.1 \\
\hline $\begin{array}{l}\text { Mapping spatial patterns with } \\
\text { morphological image } \\
\text { processing }\end{array}$ & $\begin{array}{l}\text { Vogt, Peter; Riitters, } \\
\text { Kurt H.; Estreguil, } \\
\text { Christine; Kozak, } \\
\text { Jacek; Wade, } \\
\text { Timothy G. }\end{array}$ & 2007 & 22 & 2 & 171 & 177 & 155 & 14.1 \\
\hline $\begin{array}{l}\text { The sensitivity of least-cost } \\
\text { habitat graphs to relative cost } \\
\text { surface values }\end{array}$ & $\begin{array}{l}\text { Rayfield, Bronwyn; } \\
\text { Fortin, Marie-Josee; } \\
\text { Fall, Andrew }\end{array}$ & 2010 & 25 & 4 & 519 & 532 & 112 & 14.0 \\
\hline $\begin{array}{l}\text { Identifying future research } \\
\text { needs in landscape genetics: } \\
\text { where to from here? }\end{array}$ & $\begin{array}{l}\text { Balkenhol, Niko; } \\
\text { Gugerli, Felix; } \\
\text { Cushman, Sam A. } \\
\text { et al. }\end{array}$ & 2009 & 24 & 4 & 455 & 463 & 124 & 13.8 \\
\hline $\begin{array}{l}\text { On the accuracy of landscape } \\
\text { pattern analysis using remote } \\
\text { sensing data }\end{array}$ & $\begin{array}{l}\text { Shao, Guofan; Wu, } \\
\text { Jianguo }\end{array}$ & 2008 & 23 & 5 & 505 & 511 & 133 & 13.3 \\
\hline $\begin{array}{l}\text { Effects of landscape complexity } \\
\text { on the ecological effectiveness } \\
\text { of agrienvironment schemes }\end{array}$ & $\begin{array}{l}\text { Concepcion, Elena } \\
\text { D.; Diaz, Mario; } \\
\text { Baquero, Rocio A. }\end{array}$ & 2008 & 23 & 2 & 135 & 148 & 129 & 12.9 \\
\hline $\begin{array}{l}\text { Adaptive vs. neutral genetic } \\
\text { diversity: implications for } \\
\text { landscape genetics }\end{array}$ & $\begin{array}{l}\text { Holderegger, Rolf; } \\
\text { Kamm. Urs; } \\
\text { Gugerli, Felix }\end{array}$ & 2006 & 21 & 6 & 797 & 807 & 145 & 12.1 \\
\hline $\begin{array}{l}\text { Landscape ecology, cross- } \\
\text { disciplinarity, and } \\
\text { sustainability science }\end{array}$ & Wu, Jianguo & 2006 & 21 & 1 & 1 & 4 & 139 & 11.6 \\
\hline $\begin{array}{l}\text { A standardized procedure for } \\
\text { surveillance and monitoring } \\
\text { European habitats and } \\
\text { provision of spatial data }\end{array}$ & $\begin{array}{l}\text { Bunce, R. G. H.; } \\
\text { Metzger, M. J.; } \\
\text { Jongman R. H. G.; } \\
\text { Brandt, J.; De Blust, } \\
\text { G. et al. }\end{array}$ & 2008 & 23 & 1 & 11 & 25 & 112 & 11.2 \\
\hline
\end{tabular}


Table 2 continued

\begin{tabular}{|c|c|c|c|c|c|c|c|c|}
\hline Title & Authors & $\begin{array}{l}\text { Publication } \\
\text { year }\end{array}$ & Volume & Issue & $\begin{array}{l}\text { Beginning } \\
\text { page }\end{array}$ & $\begin{array}{l}\text { Ending } \\
\text { page }\end{array}$ & $\begin{array}{l}\text { Total } \\
\text { citations }\end{array}$ & $\begin{array}{l}\text { Aveage } \\
\text { per year }\end{array}$ \\
\hline $\begin{array}{l}\text { Urban domestic gardens }(\mathrm{X}) \text { : the } \\
\text { extent and structure of the } \\
\text { resource in five major cities }\end{array}$ & $\begin{array}{l}\text { Loram, Alison; } \\
\text { Tratalos, Jamie; } \\
\text { Warren, Philip H.; } \\
\text { Gaston, Kevin J. }\end{array}$ & 2007 & 22 & 4 & 601 & 615 & 120 & 10.9 \\
\hline $\begin{array}{l}\text { Homogenization of northern US } \\
\text { Great Lakes forests due to } \\
\text { land use }\end{array}$ & $\begin{array}{l}\text { Schulte, Lisa A.; } \\
\text { Mladenoff, David } \\
\text { J.; Crow, Thomas } \\
\text { R.; Merrick, Laura } \\
\text { C.; Cleland, David } \\
\text { T. }\end{array}$ & 2007 & 22 & 7 & 1089 & 1103 & 119 & 10.8 \\
\hline $\begin{array}{l}\text { Modelling the impact of } \\
\text { agricultural abandonment and } \\
\text { wildfires on vertebrate } \\
\text { diversity in Mediterranean } \\
\text { Europe }\end{array}$ & $\begin{array}{l}\text { Moreira, Francisco; } \\
\text { Russo, Danilo }\end{array}$ & 2007 & 22 & 10 & 1461 & 1476 & 111 & 10.1 \\
\hline $\begin{array}{l}\text { Simulating feedbacks in land } \\
\text { use and land cover change } \\
\text { models }\end{array}$ & Verburg, Peter H. & 2006 & 21 & 8 & 1171 & 1183 & 119 & 9.9 \\
\hline
\end{tabular}

The articles are listed according to the number of citations per year, from high to low

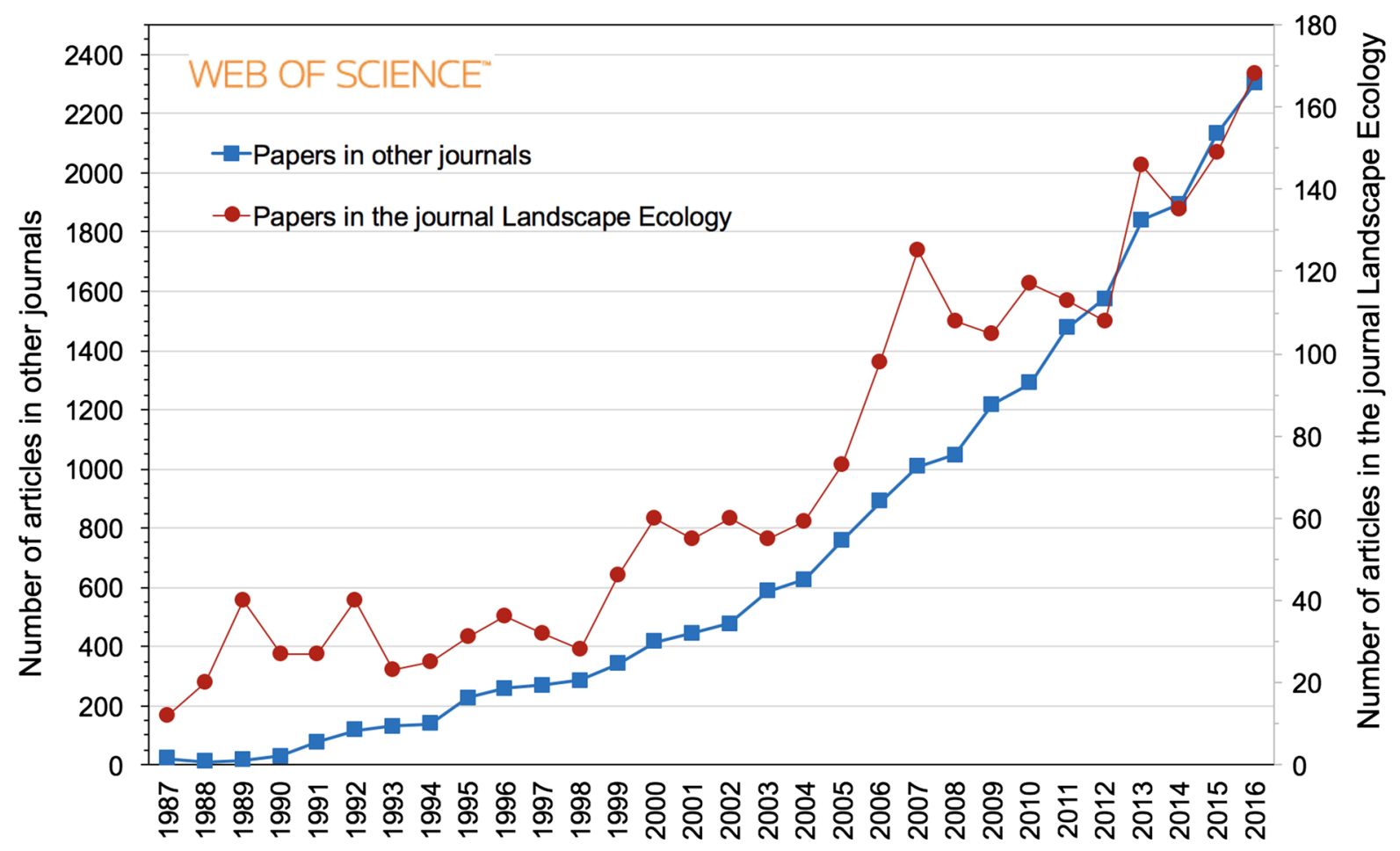

Fig. 7 The number of articles on landscape ecology published in all journals (thicker line) and in the journal, Landscape Ecology (thinner line), based on the Web of Science Core
Collection (search term $=$ "landscape" AND "ecolog*" in title, abstract, or keywords; Accessed on November 6, 2017) 


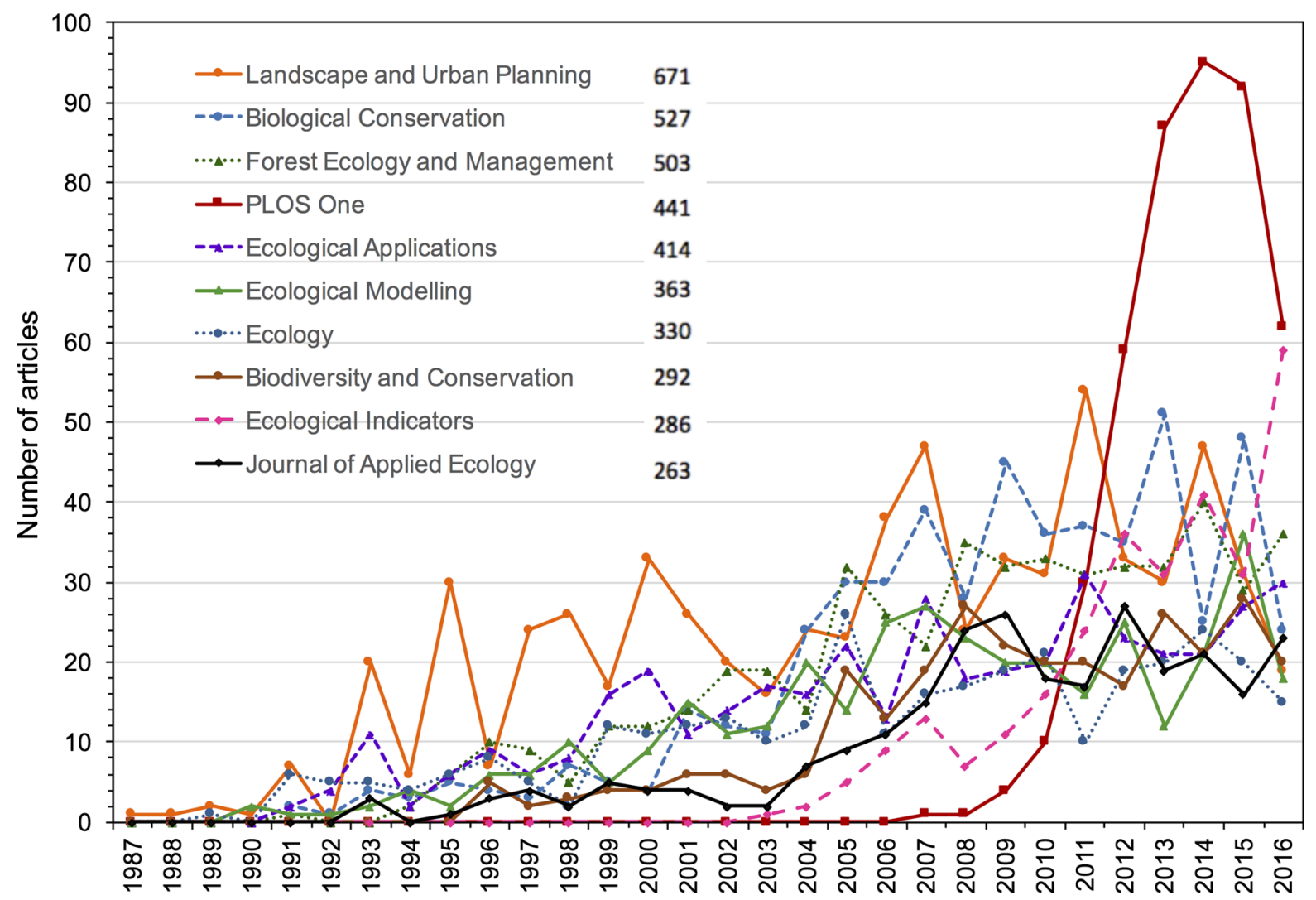

Fig. 8 Top 10 journals with most published articles on landscape ecology between 1987 and 2016 (excluding the journal, Landscape ecology), based on the Web of Science Core

performance barometer of the field as a whole. To a large extent, the articles published in the journal reflect what landscape ecologists do and how well they do it. Not surprisingly, therefore, a close scrutiny through the published pages of the journal in the past 30 years suggests that almost all well-established landscape ecologists have published influential papers in Landscape Ecology. I am sure that this will be true for the next 30 years as well.

Landscape ecology, as a flagship journal and as a field of research, has become increasingly integrative and interdisciplinary, not only influencing a number of related disciplines but also producing actionable knowledge to improve policy making and landscape planning/design. This development direction is
Collection (search term = "landscape" AND "ecolog*" in title, abstract, or keywords; Accessed on November 6, 2017)

completely consistent with what the founding Editorin-Chief, Frank Golley (1987), hoped for at the launching of the journal: the ultimate goal of landscape ecology is "to create landscapes which are beautiful, as well as productive of goods and services required by humans and natural creatures and to contribute to a system of values where landscapes can be assessed and protected for their intrinsic qualities and not only their economic worth." There is little doubt that landscape ecology today is a well-established interdisciplinary field cutting across ecological, geographical, and design sciences. With its wellestablished reputation as a mainstream journal in ecological and geographical sciences, the future of Landscape Ecology is brighter than ever. 


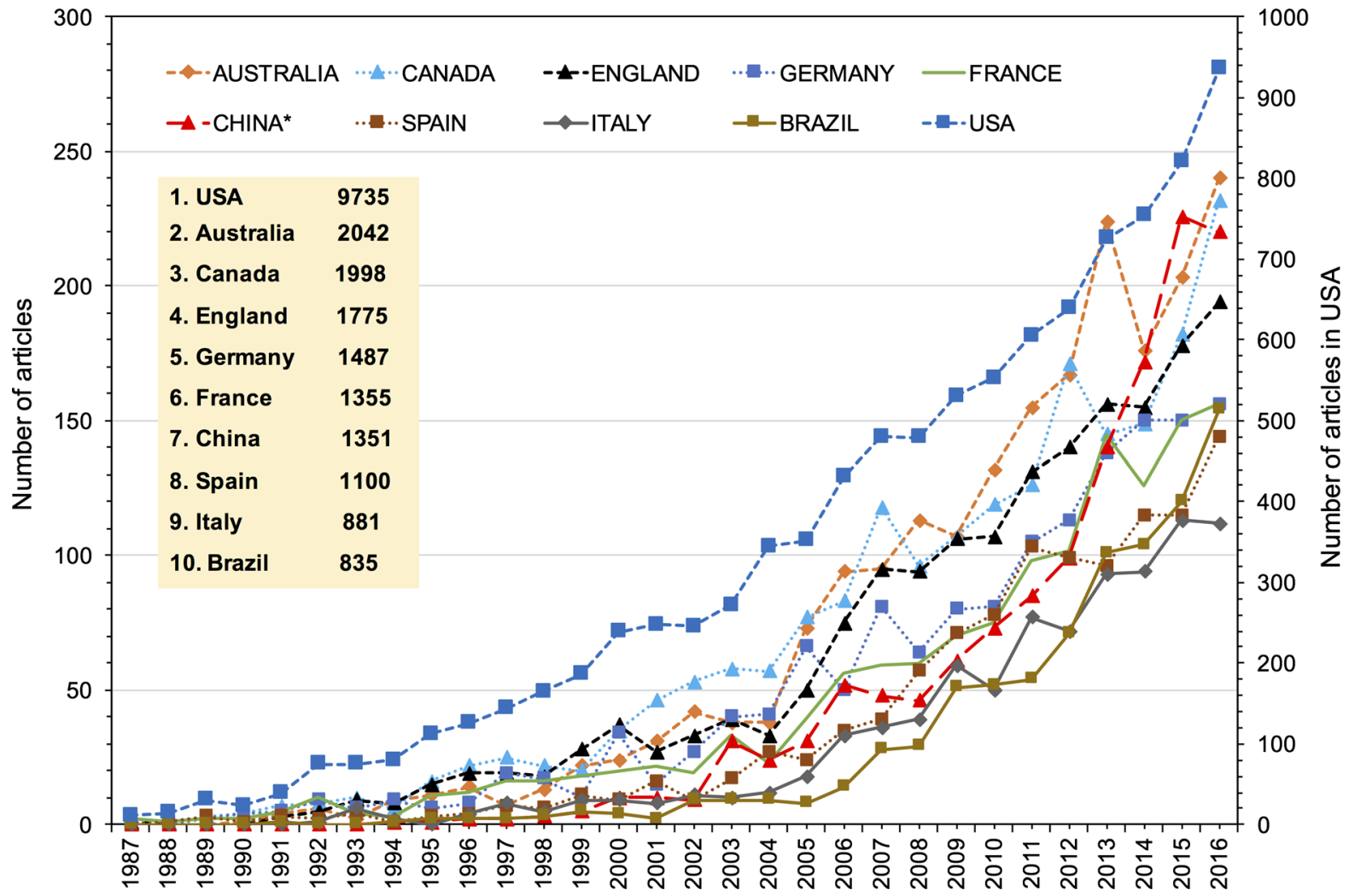

Fig. 9 Top 10 countries with most published articles on landscape ecology between 1987 and 2016, based on the Web of Science Core Collection (search term = "landscape" AND "ecolog*" in title, abstract, or keywords; Accessed on November 6, 2017)

Acknowledgements My research in landscape ecology, urban ecology, and sustainability science has been supported by several NSF Grants (NSF DEB-1342757, DEB-0618193, BCS1026865, DEB-0423704, DEB-9714833) and National Basic Research Program of China (2014CB954303, 2014CB954300). Any opinions, findings and conclusions or recommendation expressed in this material, however, are those of the author and do not necessarily reflect the views of the funding agencies. I am very grateful to my students Xuening Fang, Jingwei $\mathrm{Li}$, and Xingyue Tu for their assistance with the preparation of Figs. 5, $6,7,8$, and 9 , including literature search using Web of Science.

\section{References}

Barrett GW, Barrett TL, Wu JG (eds) (2015) History of landscape ecology in the United States. Springer, New York

Day RA, Gastel B (2006) How to write and publish a scientific paper, 6th edn. Greenwood Press, Westport, CT
Forman RTT (2015) Launching landscape ecology in America and learning from Europe. In: Barrett GW, Barrett TL, Wu JG (eds) History of landscape ecology in the United States. Springer, New York, pp 13-30

Golley FB (1987) Introducing landscape ecology. Landscape Ecol 1:1-3

Levin SA (1992) The problem of pattern and scale in ecology. Ecology 73:1943-1967

Turner MG (1989) Landscape ecology: the effect of pattern on process. Annu Rev Ecol Evol Syst 20:171-197

Turner MG (2015) Twenty-five years of United States landscape ecology: looking back and forging ahead. In: Barrett GW, Barrett TL, Wu JG (eds) History of landscape ecology in the United States. Springer, New York, pp 43-54

Wu JG (2015) History and evolution of the journal landscape ecology. In: Barrett GW, Barrett TL, Wu JG (eds) History of landscape ecology in the United States. Springer, New York, pp 55-73 